\title{
ROOT ABSORPTION AS A METHOD OF INTRODUCING INSECUCIDES INTO COCONUT PALMS FOR THE CONTROL OF LEAF-FEEDING CATERPILLARS
}

\author{
Christa Ulin Ginting and R. Desmier de Chenon ${ }^{1}$
}

\begin{abstract}
SUMMARY
The root absorption technique has been shown to be very effective method for the control of coconut leef feeding caterpillars.

However, this method, in order to be effective, requires a good system for monitoring the population level of the pest and a well organized and coordinated pest control teams.

Like the trunk injection method the root absorption technique has also many advantages: high effectiveness, good distribution of insecticides in the leaves, efficient, less harmful, long remanence does not affect the natural enen-des, thus a good method to use for integrated pest control. Furthermore, unlike the trunk injection method, the root absorption technique utilizes the root, not the trunk, of the coconut palm for introducing the pesticide. Hence, not injurious to the tree as well.
\end{abstract}

\section{INTRODUCTION}

For many years the most common methods employed for the chemical control of leaf-feeding insect pests of the coconut palm are spraying and fogging. But because these methods not only kiff the harmful pests but also the beneficial ones (e.g.) parasites and predators) and likewise, poUute the environment, the use of these methods for the control of coconut pests has become less favored.

Recently, other methods of chemical application to coconuts have, been developed to reduce, if not to entirely eliminate, the harmful effects to natural enemies and the environment. Hence, in 1954 (1) different methods of endotherapeutic treatments against coconut pests have been applied either in the stem, in the leaf rachis, or in the roots. Treatment of coconut pests through the stem (trunk injection), however, is the one widely used.

The first trial of trunk injection for the control of Rhynchophorus ferrugineus Of. was done in Sri Lanka in 1958 (14). Since then, trunk injection method has given good results for the control. of other pests of the coconut palm (Annex 1). Trunk injection, as a method, has many advantages: high effectiveness, persistence of the pesticide for at least two months, reduction of the number of treatments to only one application, not affected by climatic conditions, less harmful on the parasitoids and predators, hence a good approach to integrated pest control.

However, in spite of the many advantages of trunk injection, there are also some disadvantages. For example, the holes, made on the trunk during treatment become pennanent wounds, thus providing entry points for other pests as well as plant pathogens. Likewise, it is not advisable to make too many driffings in the stern, for repeated treatments, because too many holes in the stem'will weaken the constitution of the palm. Furthermore, small sternmed coconuts, like the dwarf varieties, can not withstand too many drillings; and these precious breeding materials should not be damaged unduly. Because of these disadvantages, other less traumatic technique has to be

\footnotetext{
1 Plant Protection Staff and Plant Protection Consultant, respectively, Punt Penelitian Kelapa (Cooonut Research Centre), Bandar Kuala, P.O. Box 16, Galang, Sumatera, Indonesia.
} 
tried. It is for this reason that the authors tried to improve the root absorption technique mentioned by Davis in 1954 (1) and later experimented by him with others for the control of Setora nitens Wlk (13) and chalcocelis albiguttata Sh (12).

The results of this improved technique of root absorption, the mechanics of its application and organization for its implementation on a large scale, particularly for the longer protection of seed gardens during the months where outbreaks generally occur, are presented in this paper.

\section{IMPROVING THE ROOT ABSORPTION TECHNIQUE}

\section{A. Prefiminary Trials}

To improve the root absorption technique for large scale application preliminary trials were conducted to determine the following: (1) absorptive capacity of roots, (2) effect of root-cut on absorptive capacity, (3) systernic insecticide best suited. for this technique, and (4) insecticide residue in young and old nuts.

The results obtained from these trials are presented below

\section{Absorptive capacity of coconut roots}

For this test the roots of the Malayan Yellow Dwarf (MYD) coconut were used. Young and old roots of two different sizes $(0.5-0.9 \mathrm{~cm}$ diameter and about $1.0 \mathrm{~cm}$ diameter) were selected and allowed to absorb $80 \mathrm{cc}$ of waters for a one day period.

Four treatments of 25 trees per treatment were set-up for this experiment. The results obtained revealed that old roots absorbed more water than the young roots regardless of size (Table 1)

Table 1. Absorptive capacity of coconut roots of different ages and sizes in one day.

\begin{tabular}{|l|l|l|l|}
\hline \multicolumn{1}{|c|}{ Treatment } & \multicolumn{1}{c|}{ Absorption $(\mathrm{cc})$} & \multicolumn{2}{c|}{ Notation of } \\
\hline & & $?=0.05$ & $?=0.01$ \\
\hline 1. Young root, $0.5-0.9 \mathrm{~cm}$ dia. & 57 & $\mathrm{c}$ & $\mathrm{B}$ \\
\hline 2. Old root, $0.5-0.9 \mathrm{~cm}$ dia. & 80 & $\mathrm{a}$ & $\mathrm{A}$ \\
\hline 3. Young root, $\pm 1 \mathrm{~cm}$ dia. & 69 & $\mathrm{~b}$ & $\mathrm{~A}$ \\
\hline 4. Old root $\pm 1 \mathrm{~cm}$ dia. & 80 & $\mathrm{a}$ & $\mathrm{A}$ \\
\hline
\end{tabular}

\section{Type of "root-cut" in relation to absorptive capacity}

Old roots of MYD coconuts were divided into two groups. One group of roots was cut vertically and the other diagonally at an angle of $60^{\circ}$. Then these roots were immersed separately in $40 \mathrm{cc}$ of water for a certain period of time.

The results showed no difference in the absorptive capacity of the roots, whether cut vertically or diagonally (Table 2). However, roots cut diagonally, because of their wedge like tips, can rupture the plastic bag (containing the insecticide) during insertion. Hence, root cut vertically is recommended. 
Table 2 Absorption capacity of roots cut verticaHy and diagonally at 600 angle.

\begin{tabular}{|l|c|}
\hline \multicolumn{1}{|c|}{ Treatment } & Absorption (cc) \\
\hline 1. Roots cut vertically with a sharp pruning scissor & 40 \\
\hline 2. Roots cut diagonally (600 angle) with a sharp knife & 38.3 \\
\hline
\end{tabular}

\section{Choice of insecticide}

For this experiment three systernic insecticides (Metamidophos, Monocrotophos, and Dicrotophos) were tested for their effectiveness in controlling Zeuxippa catoxantha, during an outbreak in PB 121 hybrids, planted in 1977.

The effectiveness of these insecticides were detennined by comparing two methods of appfications: (1) trunk injection and (2) root absorption, using one dosage rate of $5 \mathrm{~g}$ a.i. per palm.

Mortality rate was monitored three and five days after treatment. The results showed that Dicrotophos is the least effective of the three systernic insecticides, wheither the method of application is by trunk injection or by root absorption (Table 3). It was also le,ss.absorbed in the root absorption treatment.

Although both the Metarnidophos and Monocrotophos insecticides have the same effectiveness against Z. Catoxantha, Metamidophos is quite phytotoxic (9) and at the same time acts also as a contact insecticide which make this insecticide harmful to the workers and the palm. Monocrotophos, on the other hand, acts by digestion only and has no phytotoxic effect, hence more suitable for use in root absorption treatments.

Table 3. Mortality of Zeuxippa catoxantha 5 days after treatment

\begin{tabular}{|l|c|c|c|}
\hline \multirow{2}{*}{ Treatment } & \multirow{2}{*}{ \% Mortality } & \multicolumn{2}{c|}{ Notation } \\
\cline { 3 - 4 } & & 0.05 & 0.01 \\
\hline 1. Trunk injection, metamidophos & 100 & $\mathrm{~d}$ & $\mathrm{D}$ \\
2. Trunk injection, monocrotophos & 100 & $\mathrm{~d}$ & $\mathrm{D}$ \\
3. Trunk injection, docrotophos & 50.5 & $\mathrm{~b}$ & $\mathrm{~A}$ \\
4. Root absorption, Metamidophos & 100 & $\mathrm{~d}$ & $\mathrm{D}$ \\
5. Root absorption, Monocrotophos & 100 & $\mathrm{~d}$ & $\mathrm{D}$ \\
6. Root absorption, Dicrotophos & 69.7 & $\mathrm{~b}$ & $\mathrm{~B}$ \\
7. Control. & 0 & $\mathrm{c}$ & $\mathrm{C}$ \\
\hline
\end{tabular}

\section{4. hisecticidelresidue}

For the residue analysis, Monocrotopos insecticide was used at a dosage, rate of $1 \mathrm{Og}$ aj. per palm, which is twice the normal dosage rate, to facilitate the residue analysis. (A lower dose will, naturally leave a lower residue).

The test material for this experiment was the local tall variety planted in 1970. Residue analysis was done at intervals of 7,26, 57 and 117 days after treatment on both old and young nuts using the root absorption technique. 
Table 4 below shows that monocrotophos is present in both the water and albumen of both the old and young nuts even after 117 days after treatment. (According to WHO/FAO the insecticide residue tolerance is $200 \mathrm{ppb}$.). nerefore, it is best to delay consumption of the nuts for at least two months.

Table 4. Residue of Monocrotophos in old and young nuts of local tall coconuts after treatment (ppb)*

\begin{tabular}{|l|r|r|r|r|r|r|r|r|}
\hline & \multicolumn{4}{|c|}{ Old nuts } & \multicolumn{4}{|c|}{ Young nuts } \\
\hline Days after treatment & 7 & 26 & 57 & 117 & 7 & 26 & 57 & 117 \\
Water & 0.3 & 0.1 & 1.0 & 0.98 & 1.6 & 12.1 & 69.4 & 6.7 \\
Albumen & 47 & 566 & 55 & 16 & 77 & 497 & 126 & 29 \\
\hline
\end{tabular}

*Residue analysis by PAIR BATAN, Jakarta.

\section{B. MATERIALS AND METHOD FOR THE ROOT ABSORPTION TECHNIQUE}

\section{Selecdng the root}

To rind the right root for treatment, dig a hole about a meter rom the base of the tree with the use of a hoe. Select the root which is reddish in colour (old root) and which have a diameter of $1 \mathrm{~cm}$.

\section{Cutting the root}

With a diarp pnining scissors cut the root verticafly. Clean the root (about $30 \mathrm{~cm} \mathrm{long)} \mathrm{of}$ soil and small root branches before inserting the plastic bag containing the insecticide (Fig. 1).

\section{Filling-in the plastic bag with insecticide and.closing}

Use a $40 \mathrm{cc}$ plastic syringe to fill-in the plastic bag. The size of the plastic bag should be 15 $\mathrm{x} 4 \mathrm{~cm}$ to have the necessary thickness and strength to hold $40 \mathrm{cc}$ of concentrated (pure) insecticide. As soon as the plastic bag is fdled, insert carefully the prepared root. After that, tie the mouth of the plastic bag by twisting tightly a soft wire (about $8 \mathrm{~cm} \mathrm{long).}$

\section{Bending the root}

Once the plastic bag is tied to the root, bend the root down-ward at $30^{\circ}-40^{\circ}$ and secure it with a forked stick (could be made of small branch, barnboo, pieces of frond rachis, etc) to prevent the insecticide from spilling over (Fig. 2). For this, it is necessary to dig the hole deep enough in order to have about 5-10 cm free space under the root (Fig. 2).

\section{Fifiing-up the hole}

After the insecticide it all absorbed (normally 4-6 hours during the dry season, maybe longer during the rainy season), remove the plastic bag and the forked stick then cover the hole with soil to let the root grow again. The forked stick can be used again in other roots to be treated.

\section{All the materials needed for the root absorption technique are shown in Figure 3.}




\section{APPLICATION OF THE ROOT ABSORPTION TECHNIQUE AT A COCONUT SEED GARDEN}

\section{The seed garden}

In 1977 a 190 ha seed garden of MYD and MRD (Malaysian Red Dwarf) was established in Adolina, North Sumatra. The land is flat and with a high water table. Every year this seed garden is attacked by several species of insect pests. One or more species can be found at a time, but mostly those belonging to the Order Lepidoptera. At least four families in this order are commonly occurring in this seed garden: Ljmacodidae (Setora nifens w1k., Thosea b1sura Moore, chalcocelis albiguttata Sn), Pscychidae (Mahasena Corbetti Hamps), Hesperfidae (Ifidari irava moove), and Zygaenidae (Zeuxippa catoxant Hamps).

The most serious pest in the last three years, however, was Z. catoxantha Hamps. Hence, this pest was closely monitored in order to detect its development and study the dynamics of its population. During the 1984 outbreak, from January to April, chemical control, through fogging, aerial spraying and mist blower, was initiated but with little success. Hence, during the 1985 outbreak the root absorption technique was tried for its control.

\section{Pest control teams}

To properly implement the root absorption technique for the control of $\mathrm{Z}$ catoxantha on a large scale, it is necessary to create two-man teams (one man to dig the hole and prepare the roots, the other to treat the roots with insecticide). Ten two-man teams can be easily supervised by one supervisor.

\section{Treatment of trees}

The population of $Z$ catoxantha was monitored 1 week before treatment and then 1,2,3, and 4 weeks after treatment. The number of eggs, larvae and cocoons were counted from two leaf samples per hectare. The leaf samples were cut from the central part of the crown of the sample palms, when the population level of the larvae was high, treatment of the palms with monocrotophos at $5 \mathrm{~g}$, a.i. per tree was initiated. When already experienced, a team of two-man can treat 220 trees or 110 trees per worker per day of 7-hour work.

\section{4. $\quad$ Results}

Table 5 shows that $5 \mathrm{~g}$ al monocrotophos can effectively reduce the larvae population of $Z$ catoxantha for as long as one month. The per cent decrease of population during the first week after treatment was not very drastic because the eggs laid at the end of the treatment and at the beginning of the first week after treatment hatched, and the larvae were counted. Likewise, larvae in the last instar were not killed by the treatment, hence turned into cocoon. This explains the remaining population in the follow ing weeks. Although the population of imago was high it was not counted during the monitoring of the eggs, cocoons and larvae . 
Table 5. Eggs, cocoon, and larvae counts on one leaf before such after treatment with Monocrotophos at $5 \mathrm{~g}$ a.i. per tree.

\begin{tabular}{|l|r|r|r|r|r|}
\hline \multirow{2}{*}{ Stages } & \multirow{2}{*}{$\begin{array}{c}\text { Pre count before } \\
\text { treatment }\end{array}$} & \multicolumn{4}{|c|}{ Weeb after treatinent } \\
\cline { 3 - 6 } & 7.4 & 12 & \multicolumn{1}{|c|}{ II } & \multicolumn{1}{c|}{ III } & \multicolumn{1}{c|}{ IV } \\
\hline Egp + cocoons & 23.1 & 8.6 & 1.9 & 1.2 & 1 \\
Larvae & - & 32.3 & 81.9 & 89.3 & 93.2 \\
\% decrease population & & & & & \\
\hline
\end{tabular}

\section{Discussion}

Rainfall in North Sumatra is normally well distributed throughout the year with a total fall of 2,500 $\mathrm{mm}$. The fui-st semester, however, is relatively dry with a small peak in May. It is in the second semester where rainfall is high, with the highest peak in October (Fig. 4).

Plotting the population level of certain caterpillars, feeding on the leaves of coconuts in the Adolina Seed Garden, against the rainfall pattern, shows that dry months or periods of low rainfall favour population built-up. During the first semester three peaks of larvae population, above the critical level were observed and then. gradually decreased rhythmically following the life cycle during the months of heavy rain in the second sernesteriffig. 4).

In 1984 the population of $Z$ catoxantha was abnormally high because of dry weather in the previous year (1983). During this period chemical control of this pest was administered by mist blower $\left(12^{\text {th }}\right.$ week) and by fogging $\left(16^{\text {th }}\right.$ week $)$, but without success. Hence, aerial spraying was resorted to during the third peak ( $22^{\text {nd }}$ week). After this treatment, the population level of larvae dropped considerably (Fig. 5). However, this drastic drop in population could not be attributed solely to the effect of the insecticide by aerial spraying because other factors might have acted simultaneously. Such factors are rainfall and the quality and quantity of feed, which had deteriorated considerably after five months of continuous high infestation.

In 1985, the same pattern of population built-up of Z. catoxantha was again observed. When the first peak of the larvae population rose above the critical level in March (week 9), chemical control. by root absorption was promptly administered. With only one application, Z. catoxantha was successfully controlled. No other peaks of larvae population was observed and that the population level stayed low throughout the year (Fig. 5).

One probable explanations for the success of the root absorption technique in controlling $\mathrm{Z}$. catoxantha, is that when pesticide was applied no natural enernies were affected (Fig. 5), which is in contrast with mist blower, fogging and aerial spraying where ail the pests, including their natural enernies, were likewise, killed during the period of insecticide application.

Therefore, it can be concluded that the root absorption technique, is a better method of applying pesticides to coconuts for the control of leaffeeding Imae over that of trunk injection, spraying or fogging methods. This is so because through root absorption, the population of the parasitoids and predators is preserved, the palm tree is not wounded unduly, and that only one application is required for a year long protection. 
Annex 1.

Pests of the coconut palm and oil palm controlled by the trunk injection method.

\begin{tabular}{|l|l|l|c|}
\hline \multicolumn{1}{|c|}{ Order } & \multicolumn{1}{|c|}{ Name of Pest } & \multicolumn{1}{c|}{ country } & Reference \\
\hline Lepidoptera & Brassolis sophorae L. & South Africa & 10 \\
& Castnia daedelus Cr. & South Africa & 10 \\
& Zeuxippa catoxantha Hamps & Southeast Asia & 9 \\
& Thosea asigna Moore & Southeast Asia & 3 \\
& Setona nitens Wlk. & Southeast Asia & 3 \\
& Nephentis serinopa Meyrick & Southeast Asia & 8 \\
& Metisa plana & Southeast Asia & 15 \\
Hemiptera & Coelaenomenodera minuta & West Africa & 6 \\
Orthoptera & Rhinostomus barbirostris $F$. & West Africa & 7 \\
& Leptopharsa gibbicarina Froesch & South America & 2 \\
& Sexava coriacea L. (?) & Southeast Asia & 15 \\
& Graeffae crouenii (LeGuilloue) & Pacific Islands & 11 \\
\hline
\end{tabular}

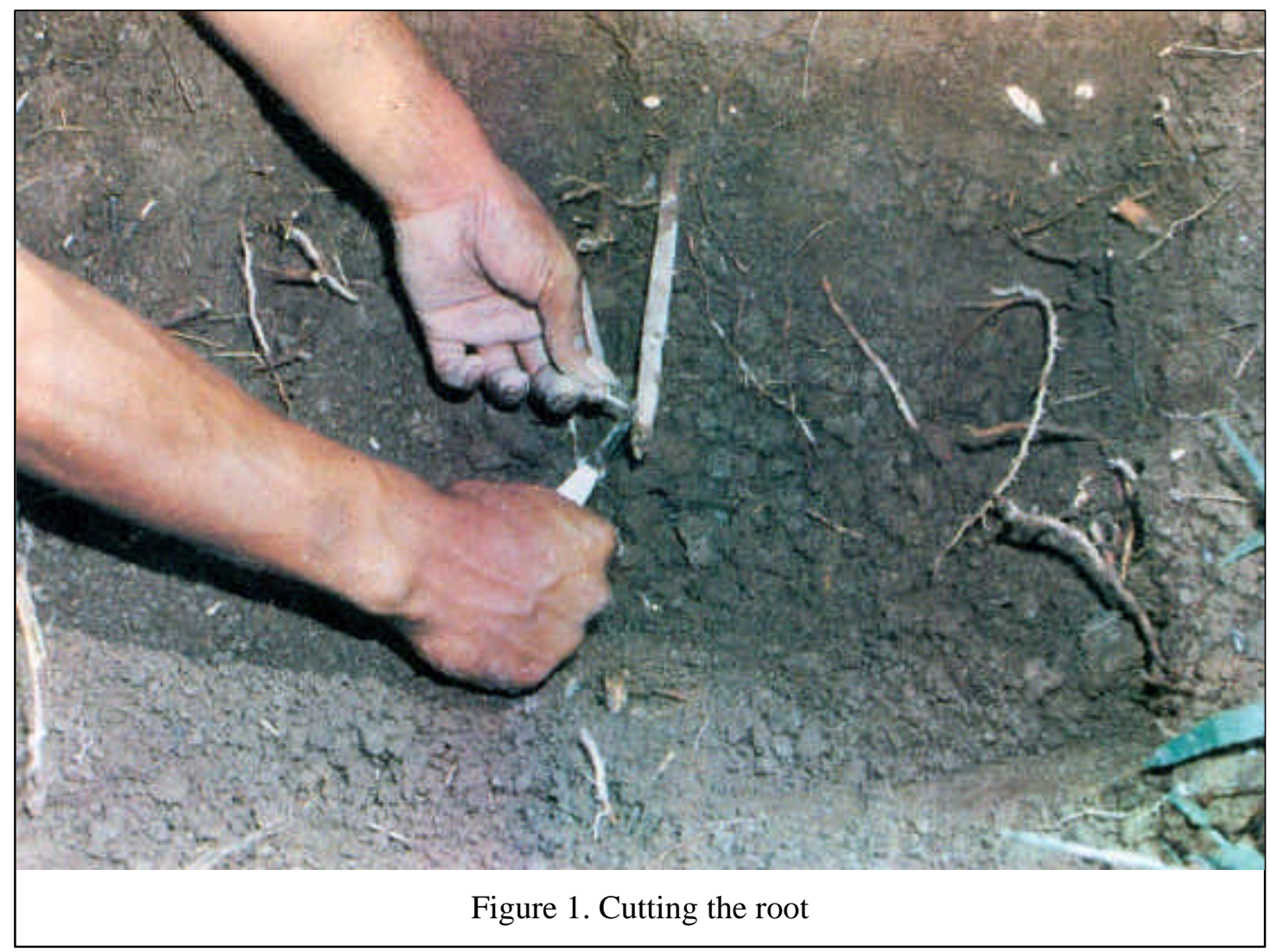



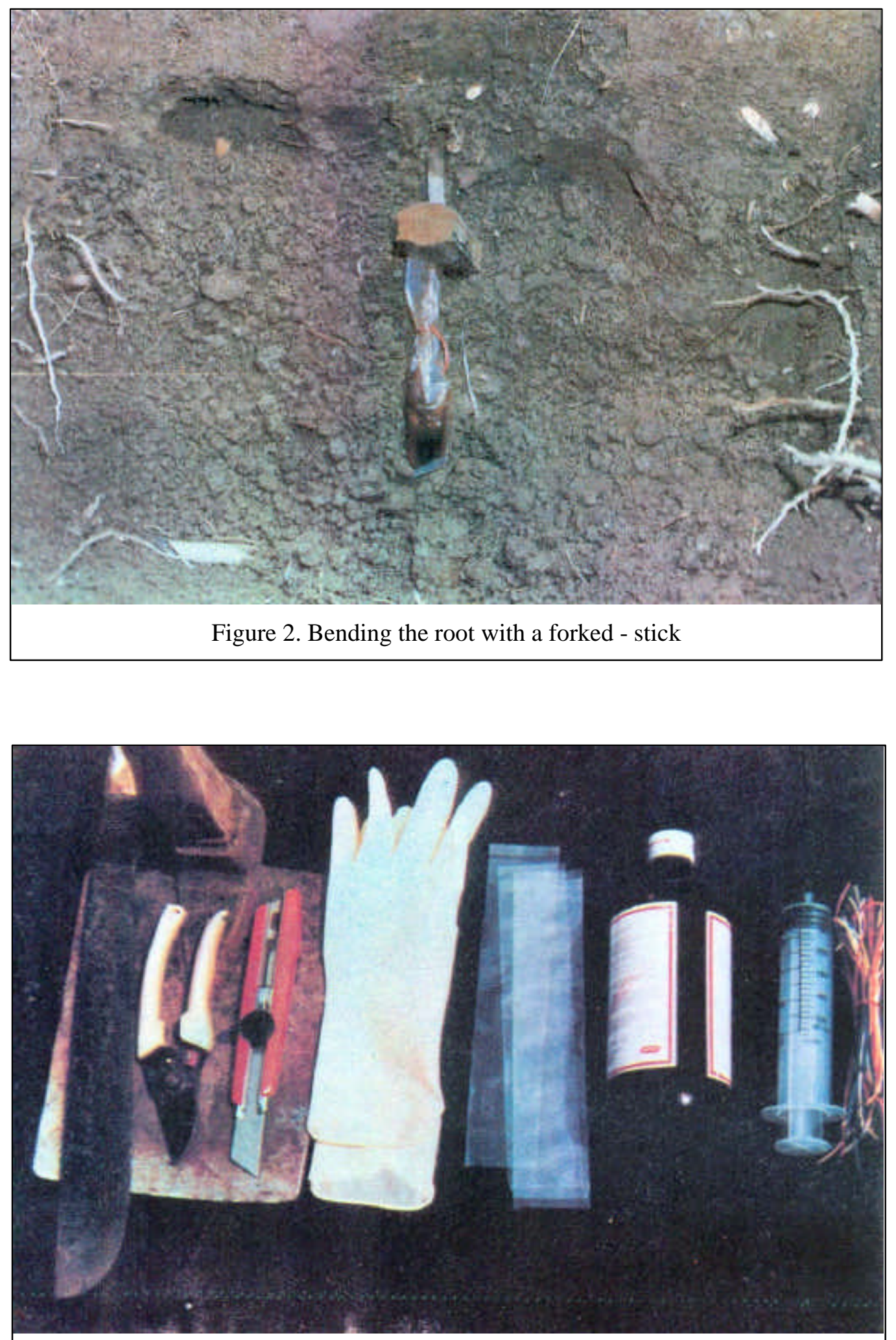

Figure 3. Materials needed for the root absorption technique. From leaft to right: Hoe, jungle knife, pruning seissor, cutting knife, surgical gloves, plastic bags, a bottle of insecticides, $40 \mathrm{cc}$ plastic syringe and $8 \mathrm{~cm}$ long softwires. 


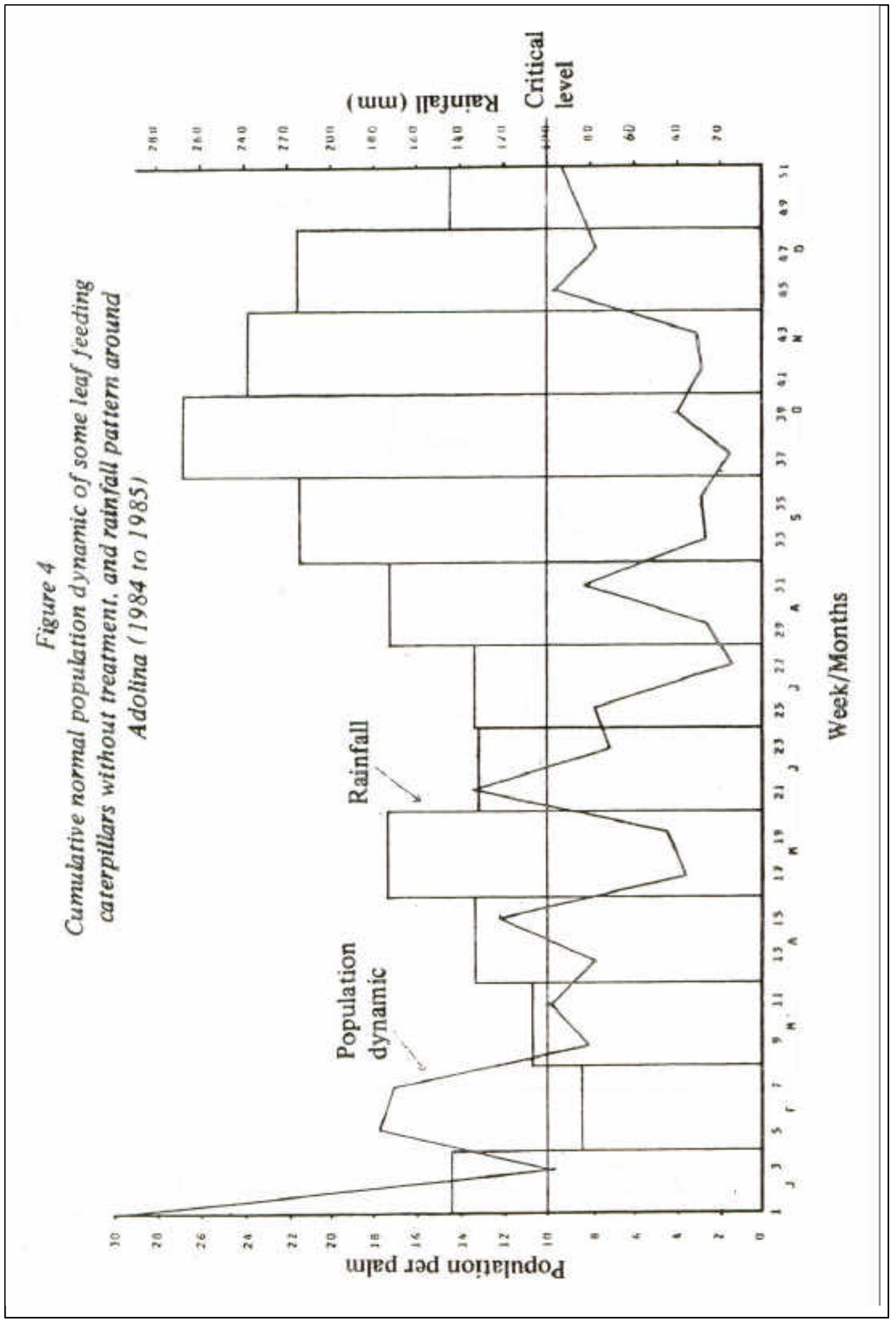


Figure 5. Cumulative population dynamic of some feding caterpillars with treatment (Adolina 1984 and 1985)

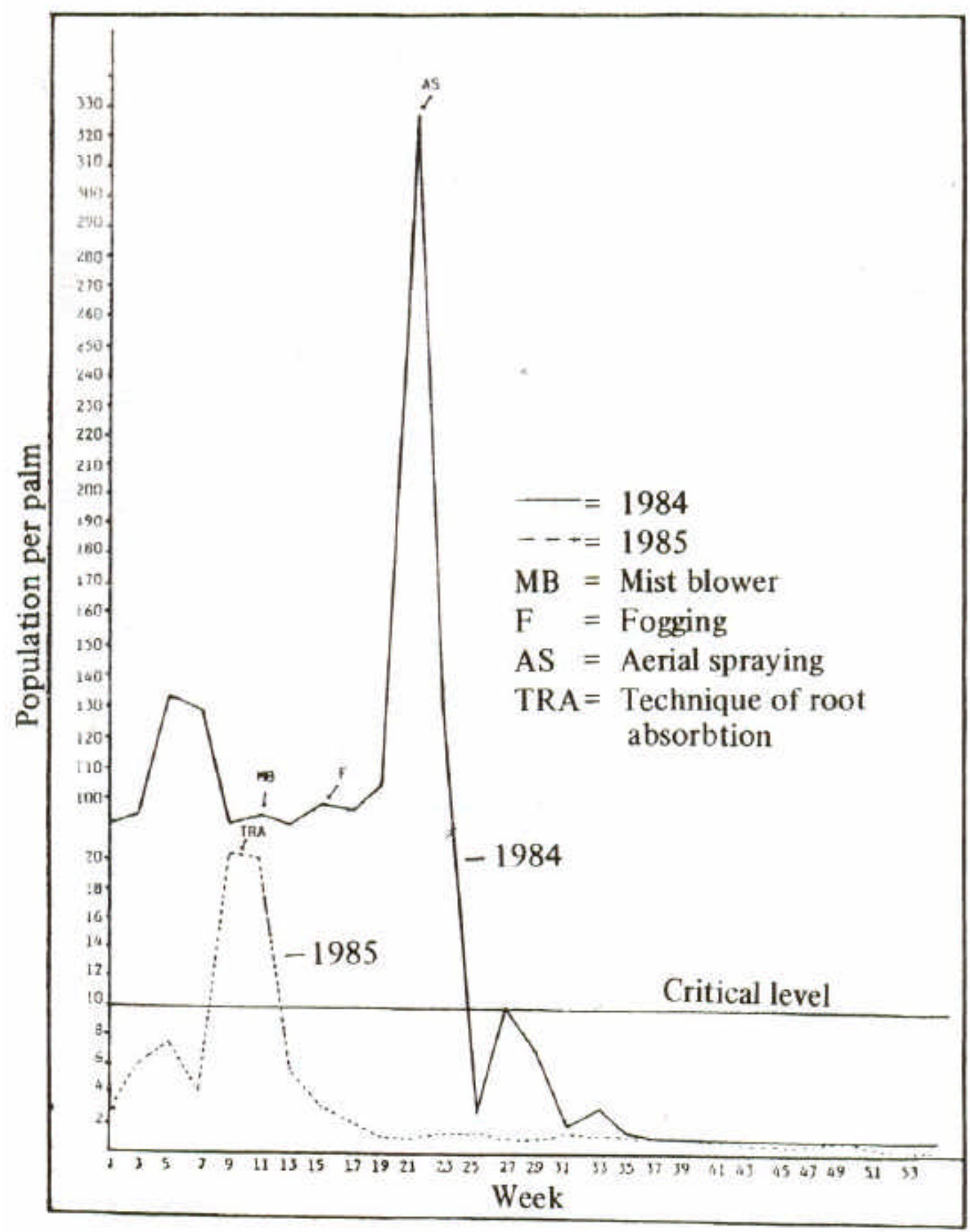




\section{REFERENCES}

1. Davis T.A., Anandan A.P. and Menon K.P.S. (1954) Injection in coconut palms for curative purposes. I Methods of injection. Indian coconut J., 7, 49 - 60.

2. Genty P., Garzon A.M. and.Garcia R. (1983) Darnage and control of the Leptopharsa Pestalotiopsis complex in oil palm. Oleagineux - Vol. 38, No. 5. fasc-404, pp-291-299.

3. Hutauruk C.J. and Sipayung A. (1978) Development of trunk injection of systemic insecticides against Setora nitens and Those asigna on oil palm in North Sumatra. Proc. PI, Prot. Conf, Kuala Lumpur, 265-278.

4. Lawes E.Q. and Webley D.J. (1961) The determination of organophorus insecticides in vegetable. Analyst, 86, 249-259.

5. Lim Guan Soon and Ramasamy S. (1 983) Pesticide application technology. Malaysian Plant Protection, 54 - 67.

6. Mariau D, Philippe R. and Morin J.P. (1979) Methode de lutre contre Coelaenomenodera (Coleoptera Hispidae) par injection d' insecticides systemiques dans le stipe du palmier a huile. Oleagineux, vol. 34, No. 2, 51-58.

7. Morin J.P. (1983) Personal Communication

8. Nadarajan L. and Channabasavanna G.P. (1981) Trunk injection of systemic insecticides against the coconut black headed caterpillar Nephantis serinopa meyrick (Lepidoptera: Cryptophasidae). Oleagineux, vol. 36, No. 5, 239-245.

9. Ooi A-C.P., Yunus A, Goh K.G. and Balosubramaniam A. (1975) Control of coconut leaf moth, Artona catoxantha Hamps. Trunk injection technique. Malaysian agric. J., 50, 2, 159-168.

10. RaiB.K.(1973) Brassolia sophorae and Castnia daedalus.- Chemical control of these major pests of coconut in Guyana. J. Econ, Ent, 66, No. 1, p. 177-180.

11. Stelzer M.J. (1970) Preliminary studies on the control of the coconut stick insect, Graeffea crouanii (Le Guilloue) with systemic insecticides. Bull ent Res, 60 p 49-5 1,

12. Soebandrijo and Luntungan H.T. (1983). Usaha pengendalian ulat Chalcocelis sp pada tanaman kelapa. Pemberitaan Penelitian Tanaman Industri Vol. VIII No. 45 January - Maret, pp. 35-44.

13. Soekarjoto S., Sudasrip H. and Davis T.A. (1980) Setora nitens, a serious sporadic insect pest of coconut in Indonesia. Planter, Kuala Lumpur, 56; p. 167 - 182.

14. Wickremasuriya C.A. (1 958). An improved injection technique for coconut palms of special relevance to the control of red weevil, Rhynchophorus ferrugineus (F). Ceylon Coconut Quart, $9(3 / 4)$, p. $40-54$.

15. Wood B. J., Liau S. S. and Knecht J.C.X. (1 974) Trunk injection of systen-dc insec6cides against the bagworm Metisa plana (lepidoptera: Psychidae) on Oil palm. Oleaginuex, 29 No. 1 1, p. 499-505.

16. Wood B.J., Hutauruk C.H. and Liau S.S. (1976) Studies on the chemical and integrated control of nettle caterpillars (Lepidoptera: Limacodidae). Malaysian International Agricultural Oil Palm Conference, Kuala Lumpur, p. 591-616. 